\title{
Antioxidant and Anticancer Activities of Polygonum Minus, Alpinia Galanga and Etlingera Elatior
}

\author{
Abdullah, MZ*, Mavaddat M.H and Mohd Ali, J \\ Department of Molecular Medicine, Faculty of Medicine, University of Malaya, 50603 Kuala Lumpur, Malaysia; E- \\ mail: zakkirun@gmail.com
}

The Malaysian traditional vegetables Polygonum minus (Pokok Kesum), Alpinia galanga (Lengkuas) and Etlingera elatior (Bunga Kantan) are commonly used in local cuisines and traditional medicine [1, 2, 3]. In this study, antioxidant and anticancer properties of extracts from these herbs were evaluated. This may provide insights on their nutritional and medicinal values. The herbs were extracted sequentially using solvents of varying polarity (apolar to polar: hexane $>$ methanol $>$ ethyl acetate $>$ water). Antioxidant activities were determined using Total Phenolic Content (TPC), Total Flavonoid Content (TFC), 2,2-Diphenyl-1picryldydrazyl (DPPH), Ferric Reducing Antioxidant Power (FRAP) and 2,2'-Azinobis (3-ethylbenzothiozoline-6-sulphonic acid) (ABTS) assays. Antiproliferation activity was assessed by MTT assay. The methanol extract of $P$. minus exhibited the highest polyphenols content. This extract also showed the highest radical scavenging activities based on DPPH and FRAP assays, which were $1276.81 \pm 12.26 \mu \mathrm{mol} \mathrm{TE} / \mathrm{g}$ and $1728.33 \pm 1.66 \mu \mathrm{mol} \mathrm{Fe}{ }^{2+} / \mathrm{g}$ extract respectively. The water extract of $P$. minus showed the highest antioxidant activity based on ABTS-radical scavenging assay. All plant extracts were evaluated for their anti-proliferative activity using colon cancer cell line HCT116, with CCD841 as the normal non-cancerous cell line for comparison. Kesum hexane extract showed promising and selective anti-proliferative activity against HCT116 cell line, with an $\mathrm{IC}_{50}$ value of $40.00 \pm 2.04 \mu \mathrm{g} / \mathrm{ml}$. This study demontrates that traditional herbs could provide sources of antioxidant and anticancer compounds.

\section{REFERENCES}

[1] Zakaria M, Mohd MA. Traditional Malay Medicinal Plants, Itnm 2010.

[2] Ohd Jaafar F, Osman CP, Ismail NH, Awang K. Analysis of essential oils of leaves, stems, flowers and rhizomes of Etlingera Elatior (Jack) R. M. Smith. Malay J Anal Sci 2007; 1: 269-73.

[3] Oonmetta-aree J, Suzuki T, Gasaluck P, Eumkeb G. Antimicrobial properties and action of galangal (Alpinia galanga Linn.) on Staphylococcus aureus. LWT-Food Sci Technol 2006; 39: 1214-20. 